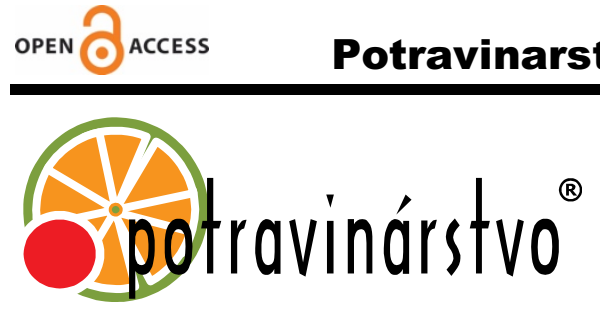

Potravinarstvo Slovak Journal of Food Sciences vol. 13, 2019, no. 1, p. 875-883

https://doi.org/10.5219/1226

Received: 26 September 2019. Accepted: 11 November 2019. Available online: 28 November 2019 at www.potravinarstvo.com (C) 2019 Potravinarstvo Slovak Journal of Food Sciences, License: CC BY 3.0

ISSN 1337-0960 (online)

\title{
STUDY OF CHEMICAL STRUCTURE, ANTIMICROBIAL, CYTOTOXIC AND MECHANISM OF ACTION OF SYZYGIUM AROMATICUM ESSENTIAL OIL ON FOODBORNE PATHOGENS
}

\author{
Behrooz Alizadeh Behbahani, Mohammad Noshad, Fereshteh Falah
}

\begin{abstract}
In this study, chemical composition (gas chromatography-mass spectroscopy), chemical structure (fourier transform infrared spectroscopy) and antioxidant potential ( $\beta$-carotene bleaching assay and DPPH/ABTS-radical scavenging activity tests) of Syzygium aromaticum essential oil (SAEO) were evaluated. Eugenol (75.11\%) was found to be the major compound of SAEO. Eugenol, as the main chemical constituent of SAEO, showed its signature peaks in the wavenumber range of $720-1250 \mathrm{~cm}^{-1}$, ascribing to the $\mathrm{C}=\mathrm{C}$ region. The antimicrobial activity of SAEO on Escherichia coli, Staphylococcus aureus, Listeria innocua and Pseudomonas aeruginosa were evaluated. The scanning electron microscopy (SEM) was then applied to unravel the antibacterial mechanism of SAEO on E. coli as the most resistant strain and L. innocua as the most sensitive strain. The MTT assay was also used to investigate the cytotoxicity effect of SAEO on human colonic cancer cell lines (HT29 cell line) and the highest cytotoxic effect was observed at $200 \mathrm{mg}^{-\mathrm{mL}^{-1}}$ concentration of SAEO. The SEM micrographs revealed that the SAEO treatment was able to manifestly increase the cell permeabilization and membrane integrity disruption. This means that the entirety of the cell membranes was remarkably affected by the essential oil, which could lead to cytoplasm secretion and subsequent cell death. The data strongly suggest that SAEO had a potential antioxidant, antimicrobial and cytotoxicity activity.
\end{abstract}

Keywords: Syzygium aromaticum; Scanning electron microscopy; Cytotoxic effect; Antimicrobial activity; HT29 cell line

\section{INTRODUCTION}

In recent years, foodborne pathogenic and spoilage bacteria have led to the emergence of one of the important food safety challenges, i.e. new foodborne disease outbreaks (Zhang et al., 2016). It is also worthwhile to note that the lipid oxidation reaction could lead to the formation of potentially toxic side-reaction products capable of threating human health (Zhong et al., 2015). In these contexts, chemical synthetic preservatives have been frequently used in the food industry to suppress microbial growth and lipid oxidation reaction; however, their usages have been a controversial topic, owing to their potential to create health problems (López-Malo et al., 2006; Spickett and Forman, 2015). Therefore, there is a necessity to seek new and safe food-grade antioxidant and antimicrobial agents to amend food shelf-lives. Essential oils (EO) derived from aromatic plants have gained a lot of attention in the food industry not only for their natural origin, but also due to their documented benefits in food and human health. These biologically active compounds confer versatile biological characteristics including antimicrobial, insecticidal, antioxidant, analgesic, anti-tumor, anti- inflammatory, and anti-diabetic effects (Ribeiro-Santos et al., 2017). Syzygium aromaticum L. (clove) is known as an evergreen tree and its commercial products are cloves, clove oil, and oleoresin. The essential oil of $S$. aromaticum is normally extracted from its stem, unopened buds, and leaves. Clove oil is used in dental formulations, toothpaste, soaps, mouth washes, breath freshner, insect repellent, and cosmetic items owing to different kind of biological properties, such as antibacterial, antifungal, anthelmintic, analgesic, and anti-carcinogenic activities (Srivastava, Srivastava and Syamsundar, 2005). Eugenol is the major chemical compound of $S$. aromaticum essential oil (SAEO) which its antibacterial and antifungal activities have been reported in the literature (Shokeen et al., 2008; Braga et al., 2007). However, as seen in the literature and to the best of authors' knowledge, there is no data available indicating the mechanism of antimicrobial activity of SAEO towards pathogenic and spoilage bacteria. This study was therefore aimed to unravel the antibacterial effect of SAEO through mechanistic approaches to provide more insights into the mode of 
antibacterial action. Moreover, the antioxidant activity of the bioactive essential oil was investigated in this study.

\section{Scientific hypothesis}

The essential oil of Syzygium aromaticum has outstanding antibacterial effect against food-borne spoilage and pathogenic bacteria, in conjugation with superb radical scavenging activity.

\section{MATERIAL AND METHODOLOGY \\ Materials}

S. aromaticum were procured from a local market (Ahwaz, Iran). $\quad \beta$-carotene, linoleic acid, 2,2-Diphenyl-1picrylhydrazyl (DPPH), 2,2'-azinobis (3ethylbenzothiazoline-6-sulphonic acid) diammonium salt) (ABTS), gallic acid, and quercetin were purchased from Sigma-Aldrich Co. (St Louis, MO, USA). Other chemical reagents and materials were of analytical grade and purchased from Sigma-Aldrich Co. (St Louis, MO, USA) or Merck Co. (Germany).

\section{Essential oil extraction}

The plant was firstly verified and then dried at room temperature in a dark place, followed by grinding to obtain powdered forms via a laboratory grinder. The powdered plant $(20 \mathrm{~g})$ was dispersed in distilled water $(750 \mathrm{~mL})$ and the resulting dispersion was then subjected to a hydrodistillation-based Clevenger apparatus for $3.0 \mathrm{~h}$, according to a method introduced by Behbahani and Shahidi (2019) with some modification. The extracted essential oil (SAEO) was dried using anhydrous sodium sulfate followed by storing at $4{ }^{\circ} \mathrm{C}$ in glass vials until analyses.

\section{Essential oil analysis}

\section{Gas chromatography-mass spectroscopy (GC-MS)}

GC-MS technique was applied to identify the main chemical compounds of SAEO, based on the method of Behbahani et al., (2017a). For this purpose, $0.2 \mu \mathrm{L}$ of SAEO was injected to the GC column and the separation of chemical compounds of the essential oil was performed at the heating rate of $5{ }^{\circ} \mathrm{C} \cdot \mathrm{min}^{-1}$ and the ionization energy of $70 \mathrm{eV}$ that was provided by the carrier gas helium with a rate of $1.1 \mathrm{~mL} \cdot \mathrm{min}^{-1}$. A sequential process consisted of the comparison of normal spectra of chemical compounds with those of alkenes $\left(\mathrm{C}_{8}-\mathrm{C}_{28}\right)$, the calculation of Kovats retention index, and the referring of the resulting indices to the natural compounds library was then used to identify the main chemical constituent of SAEO.

\section{Fourier transform infrared spectroscopy (FTIR)}

The essential oil was mixed with potassium bromide followed by compressing the mixture to obtain an appropriate pellet. The FTIR spectrum of the essential oil was then recorded in the wavenumber range of $500-4000 \mathrm{~cm}^{-1}$ with $4 \mathrm{~cm}^{-1}$ resolution using a Perkin Elmer model FTIR spectrometer.

\section{Total phenol content}

The procedure of Do et al. (2014) with minor changes was employed to measure the total phenol content of the SAEO. Briefly, $0.10 \mathrm{~mL}$ of the sample was added to
$1.0 \mathrm{~mL}$ of $10 \% \mathrm{v} / \mathrm{v}$ Folin-Ciocalteu reagent. The resulting solution was vortexed for $5.0 \mathrm{~min}$ and it was then charged with $0.30 \mathrm{~mL}$ of $10 \% \mathrm{Na}_{2} \mathrm{CO}_{3}$ solution. After incubation of the solution at ambient temperature for $2.0 \mathrm{~h}$, its absorbance was read at $760 \mathrm{~nm}$. Gallic acid was used as standard $\left(0-0.50 \mathrm{mg} \cdot \mathrm{mL}^{-1}\right)$ and the total phenol content of the SAEO was expressed as mg gallic acid equivalent per $\mathrm{g}$ dried essential oil.

\section{Total flavonoid content}

The total flavonoid content of the sample was determined utilizing the method of Tohidi, Rahimmalek and Arzani (2017), with some modification. The SAEO $(0.10 \mathrm{~mL}$; $0.10 \mathrm{mg} \cdot \mathrm{mL}^{-1}$ ) was charged and mixed with $0.30 \mathrm{~mL}$ of $5.0 \% \mathrm{NaNO}_{2}$ solution. $\mathrm{AlCl}_{3}(0.30 \mathrm{~mL} ; 10 \% \mathrm{w} / \mathrm{v})$ was added and the solution was mixed for $6.0 \mathrm{~min}$, followed by adding $2.0 \mathrm{~mL}$ of $\mathrm{NaOH}$ solution $(1.0 \mathrm{M})$. The absorbance of the obtained solution was recorded at $510 \mathrm{~nm}$ and quercetin was applied as standard $\left(0-0.5 \mathrm{mg} \cdot \mathrm{mL}^{-1}\right)$. The total flavonoid content was then calculated and recorded as mg quercetin per $\mathrm{g}$ dried essential oil.

\section{Antioxidant assays}

DPPH-radical scavenging (DPPH-RS) activity: SAEO $(100 \mu \mathrm{L})$ was charged and mixed with ethanolic solution of DPPH radicals $(0.12 \mathrm{mM} ; 3.90 \mathrm{~mL})$. The resulting solution was kept at ambient temperature in a dark place for $30 \mathrm{~min}$ and its absorbance was read at $517 \mathrm{~nm}$. DPPHRS activity of SAEO was then measured as below (Behbahani, Noshad, and Falah, 2019).

$$
\text { DPPH-RS activity }(\%)=[1-\mathrm{A} \text { sample/A control }] \times 100
$$

Where: A sample and A control are the absorbance of the sample and control (distilled water instead of sample), respectively.

ABTS-radical scavenging (ABTS-RS) activity: The method of Shan et al. (2005) was used to evaluate the ABTS-RS activity of the essential oil. ABTS ${ }^{\circ}$ cations were firstly generated by reacting the same volumes of ABTS $(7.0 \mathrm{mM})$ and potassium persulfate $(2.45 \mathrm{mM})$ solutions following keeping the obtained solution at room temperature, under dark conditions for $16 \mathrm{~h}$. The ABTS solution was then diluted with methanol to reach $0.70 \pm 0.20$ absorbance at $734 \mathrm{~nm}$. Thereafter, $3.90 \mathrm{~mL}$ of the diluted ABTS ${ }^{\circ}$ solution was mixed with SAEO $(0.10 \mathrm{~mL})$ or methanol $(0.10 \mathrm{~mL}$; as control sample). The solution was stored for $6.0 \mathrm{~min}$ at ambient temperature and the absorbance was measured at $734 \mathrm{~nm}$. The ABTS-RS activity of the essential oil was calculated according to the following equation:

$$
\text { ABTS-RS activity }(\%)=[1-\mathrm{As} / \mathrm{Ac}] \times 100
$$

Where: As indicates the absorbance of the samples and Ac stands for the absorbance of the control.

$\beta$-carotene-linoleic acid assay: The inhibitory effect of SAEO against the bleaching of $\beta$-carotene-linoleate solution was evaluated via a spectrophotometric method based on the below equation (Dapkevicius et al., 1998): 
Inhibitory effect $(\%)=\left[\left(\mathrm{AA}_{(120)}-\mathrm{AC}_{(120))}\right) /\left(\mathrm{AC}_{(0)}-\mathrm{AC}_{(120))}\right]\right.$ $\times 100$

Where: $\mathrm{AA}_{(120)}$ is the absorbance (at $490 \mathrm{~nm}$ ) of sample after 120 min incubation time, and $\mathrm{AC}_{(0)}$ and $\mathrm{AC}_{(120)}$ are the absorbance of control sample at time zero and after 120 min incubation time, respectively.

\section{Antibacterial assays}

The antibacterial effect of the essential oil (SAEO) was evaluated towards Escherichia coli ATCC 25922, Pseudomonas aeruginosa ATCC 27853, Staphylococcus aureus ATCC 25923, and Listeria innocua ATCC 33090, according to the following antimicrobial tests.

Disk diffusion agar (DDA) assay: This antimicrobial test was done based on the method of Noshad, Hojjati, and Behbahani (2018) with minor changes. The blank discs were firstly impregnated with $20 \mu \mathrm{L}$ of SAEO for $15 \mathrm{~min}$ at ambient temperature, followed by placing them on the culture media that were previously contaminated with bacterial strains. The media were incubated at $37{ }^{\circ} \mathrm{C}$ for $24 \mathrm{~h}$ and the inhibition zone areas around discs were determined by a ruler $(\mathrm{mm})$ and expressed as antibacterial activity.

Well diffusion agar (WDA) assay: The WDA test was performed utilizing a procedure introduced by Behbahani and Fooladi (2018). In this antibacterial assay, several holes with $6.0 \mathrm{~mm}$ in diameter were firstly created on the surface of Mueller Hinton agar medium (contaminated with bacteria) and then charged with $20 \mu \mathrm{L}$ of SAEO. The inhibition zones around the holes were measured after incubation of the medium at $37^{\circ} \mathrm{C}$ for $24 \mathrm{~h}$, and reported as antibacterial effect.

Minimum inhibitory concentration (MIC) assay: The MIC of SAEO was evaluated using the microdilution assay in 96 well plates, according to the modified method of Yeganegi et al. (2018). Sequential concentrations of SAEO $(0.39,0.781,1.562,3.125,6.25,12.5,25,50,100$, $200 \mathrm{mg} \cdot \mathrm{mL}^{-1}$ ) were prepared in Mueller Hinton broth medium and then sterilized through syringe filters $(0.45 \mu \mathrm{m})$. In the next step, $200 \mu \mathrm{L}$ of each concentration was added to the wells containing $20 \mu \mathrm{L}$ of microbial suspensions with $0.5 \mathrm{McF}$ arland equivalent. The plates were stored at a constant temperature of $37^{\circ} \mathrm{C}$ for $24 \mathrm{~h}$ and they were incorporated with $20 \mu \mathrm{L}$ of $5.0 \% \mathrm{w} / \mathrm{v} 2,3,5-$ triphenyltetrazolium chloride solution. The plates were reincubated and the lowest concentration of SAEO that inhibited the growth of bacterial strains (confirmed by the lack of an amethystine or dark red color in the wells), was considered as the MIC of the essential oil.

Minimum bactericidal concentration (MBC) assay: In this antibacterial test, $100 \mu \mathrm{L}$ of the solution in microbial growth-free wells (based on the MIC results) was cultured on the surface of Mueller Hinton agar medium, followed by incubation at $37{ }^{\circ} \mathrm{C}$ for $24 \mathrm{~h}$. The lowest SAEO concentration that killed the bacterial strains (no visible colony formation) was reported as the $\mathrm{MBC}$ of the essential oil (Alghooneh et al., 2015).

\section{Antibacterial mechanism}

Scanning electron microscopy (SEM) was performed to unravel the mechanism of action of SAEO on cell membranes of the most sensitive and resistant bacteria to the essential oil (i.e., L. innocua and E. coli, respectively), following the method of Lv et al. (2011) and Moghayedi et al. (2017), with minor changes. For this aim, the microorganisms were cultured in a broth medium at their MIC values and incubated at $37{ }^{\circ} \mathrm{C}$ under shaking conditions. Next, the microbial suspension was centrifuged for $5.0 \mathrm{~min}$ at $5000 \mathrm{~g}$, and the precipitate (contains microorganisms) was washed twice with phosphate buffered solution $(0.10 \mathrm{M}, \mathrm{pH} 7.0)$. The suspension was filtered using a polycarbonate filter and the filtrate was fixed in a glutaraldehyde solution $(2.50 \% \mathrm{v} / \mathrm{v})$, which was followed by keeping the solution at $4{ }^{\circ} \mathrm{C}$ for $2.0 \mathrm{~h}$. The sample was washed several times with double distilled water and it was then dehydrated successively with ethanol solution of various concentrations $(30 \%, 50 \%, 70 \%, 80 \%$, $90 \%$, and $100 \%$ ) for $10 \mathrm{~min}$. In the final step, the samples were dried to completely evaporate the ethanol and coated with gold for SEM analysis. The morphology of E. coli and $L$. innocua was checked before and after treatment with SAEO, using a LEO 1450 VP model SEM apparatus.

\section{Cytotoxicity effect of SAEO}

The cytotoxic effect of SAEO was measured against colon cancer cell line (HT29 cell line) by MTT assay. The cells $(\mathrm{Bu}$ Ali Research Institute of Mashhad, Iran) were cultured in DMEM (Dulbecco's Modified Eagle Medium) high glucose medium supplemented with fetal calf serum $(10 \% \mathrm{v} / \mathrm{v})$ and penicillin/streptomycin, and incubated at $37{ }^{\circ} \mathrm{C}$ under constant humidity $95 \%$ and $5.0 \% \mathrm{CO}_{2}$ pressure. HT29 cells were seeded in 96-well flat-bottom plates (approximately 100,000 per well) until 50-60\% confluence was achieved. The medium was then replaced with a complete culture medium containing DMEM and fetal bovine serum $(200 \mu \mathrm{L})$ and various concentrations of SAEO $(0.39,0.781,1.562,3.125,6.25,12.5,25,50,100$, $200 \mathrm{mg} \cdot \mathrm{mL}^{-1}$ ) were added to each well. The blank medium was regarded as control medium. The cell proliferation was quantified by MTT 3-(4,5-dimethylthiazol-2-yl)-2,5diphenyltetrazolium bromide assay after $24 \mathrm{~h}$ incubation time as follows. The MTT solution $\left(30 \mu \mathrm{L} ; 5.0 \mathrm{mg} \cdot \mathrm{mL}^{-1}\right)$ was added to each well and the plates were incubated for $3.0 \mathrm{~h}$ in a $\mathrm{CO}_{2}$-equiped incubator. After removing the medium gently and adding DMSO $(200 \mu \mathrm{L})$ into the wells, an ELISA/microplate reader at $570 \mathrm{~nm}$ reference filter was used to record the absorbance of the mixture. The SAEO concentration $\left(\mathrm{mg} . \mathrm{mL}^{-1}\right)$ that was able to inhibit the cell growth by $50 \%$, was calculated and defined as $\mathrm{IC}_{50}$. The cell viability curves were plotted with regard to the control cells.

\section{Statistic analysis}

All the experiments were done at three replicates. Data were analyzed through one-was ANOVA by SPSS software at $95 \%$ confidence level $(p<0.05)$, and recorded as means \pm standard deviation. 


\section{RESULTS AND DISCUSSION}

\section{Chemical composition of SAEO}

Six compounds were confirmed in SAEO according to the GC-MS analysis, with eugenol being the main detected constituent among others (75.11\%). Caryophyllene $(14.05 \%)$ was the second bioactive compound identified in SAEO, followed by phenol, 2-methoxy-4-(2-propenyl) $(6.09 \%)$ and humulene $(3.35 \%)$. Other minor constituents were delta-cadinene $(0.71 \%)$ and caryophyllene oxide $(0.69 \%)$. The results are in congruent with findings of other researchers, who reported that eugenol is the main biologically active compound of the essential oil of $S$. aromaticum (Cortés-Rojas, de Souza and Oliveira, 2014; Ranasinghe, Jayawardena and Abeywickrama, 2002).

\section{Structural analysis of SAEO}

The FTIR spectrum of SAEO obtained via the hydrodistillation method is depicted in Figure 1. The region of $3000-3500 \mathrm{~cm}^{-1}$ is due to the hydroxyl $(\mathrm{OH})$ groups of phenolic and alcoholic compounds of SAEO. The peaks at around $2847 \mathrm{~cm}^{-1}$ and $2937 \mathrm{~cm}^{-1}$ are attributed to the frequency asymmetrical patterns of $\mathrm{CH}_{2}$ - and $\mathrm{CH}_{3}$ - groups of alcoholic compounds in the essential oil (Mohammed, Abdulkadhim and Noori, 2016). Eugenol, as the main chemical constituent of SAEO, showed its signature peaks in the wavenumber range of $720-1250 \mathrm{~cm}^{-1}$, ascribing to the $\mathrm{C}=\mathrm{C}$ region. Moreover, the sharp peaks at 1642.22 , 1607.06 , and $1513.75 \mathrm{~cm}^{-1}$ are assigned to the $\mathrm{C}=\mathrm{C}$ stretching vibration of aromatic moiety of eugenol, in well agreement with the eugenol spectrum reported by Pramod et al. (2015). The peak at $1268 \mathrm{~cm}^{-1}$ could be ascribed to the characteristic bands of $=\mathrm{C}-\mathrm{H}$ in-plane bending absorption of the aromatic rings and $-\mathrm{CH}_{2}$ swing in alkanes; whilst, the peak at $1234 \mathrm{~cm}^{-1}$ is likely due to the $\mathrm{C}-\mathrm{O}-\mathrm{C}$ symmetric expansion of aromatic acid esters and $\mathrm{C}-\mathrm{OH}$ vibrational stretching of phenolic compounds, which the latter peak is often attributed to the absorption of esters and eugenol in essential oils (Jeyaratnam et al., 2016. The peaks located at the wavenumbers of $1122 \mathrm{~cm}^{-1}$ and $1035 \mathrm{~cm}^{-1}$ are probably ascribed to the $\mathrm{C}-\mathrm{O}$ stretching vibrations and deformation vibration of $\mathrm{C}-\mathrm{OH}$ groups. In addition, the peaks at $992 \mathrm{~cm}^{-1}$ and $743 \mathrm{~cm}^{-1}$ could be due to the bending vibration absorption of $\mathrm{C}-\mathrm{H}$ groups and $=\mathrm{CH}$ vibration absorption of benzene rings, respectively. Likewise, the vibration absorption of alkenes could be observed at the wavenumber of $645 \mathrm{~cm}^{-1}(\mathbf{L i}$, Kong and Wu, 2013).

\section{The content of total phenolic and flavonoid compounds}

S. aromaticum is one of the main vegetal sources of phenolic compounds, such as flavonoids, hydroxyphenyl propens, hydroxycinamic acids, and hydroxybenzoic acids. The total phenolic and flavonoid compounds of the essential oil were found to be $48.14 \pm 0.12 \mathrm{mg}$ gallic acid. $\mathrm{g}^{-1}$ and $23.26 \pm 0.51 \mathrm{mg}$ quercetin. $\mathrm{g}^{-1}$ dry weight of the SAEO. Phenolic acids such as gallic acid and its derivatives (e.g., hydrolysable tannins) are found in high concentration in clove oil. Flavonoid compounds like kaempferol, quercetin, and its glycosylated derivatives are also presented in clove in lower contents (Cortés-Rojas et al., 2014). Total phenolic content of $0.0896 \mathrm{mg}$ gallic acid. $^{-1}$ dry weight of $S$. aromaticum fruit and $114.41-519.33 \mathrm{mg}$ gallic acid. ${ }^{-1}$ S. aromaticum extracts have been reported by Wojdyło, Oszmiański and Czemerys (2007) and Neaz (2019), respectively. These differences could be ascribed to the various extraction techniques and plant parts used for essential oil extraction. Indeed, the oils from the bud, stem, and leaves of clove differ considerably in quality and yield. In addition, the origin, variety, maturity at harvest, and quality of raw materials in conjugation with pre-treatments and extraction modes can influence both yield and composition of the resulting essential oil (Neaz, 2019). Phenolic compounds are strongly contributed to the antioxidant and antimicrobial capacity of bioactive EO.

\section{Antioxidant activity}

DPPH-RS, ABTS-RS, and $\beta$-carotene bleaching assays were applied to evaluate the antioxidant activity of SAEO. The relatively stable organic DPPH radical has been extensively used to determine the antioxidative potential of plant extracts and single compounds (Goupy et al., 2003; Zhang et al., 2019).

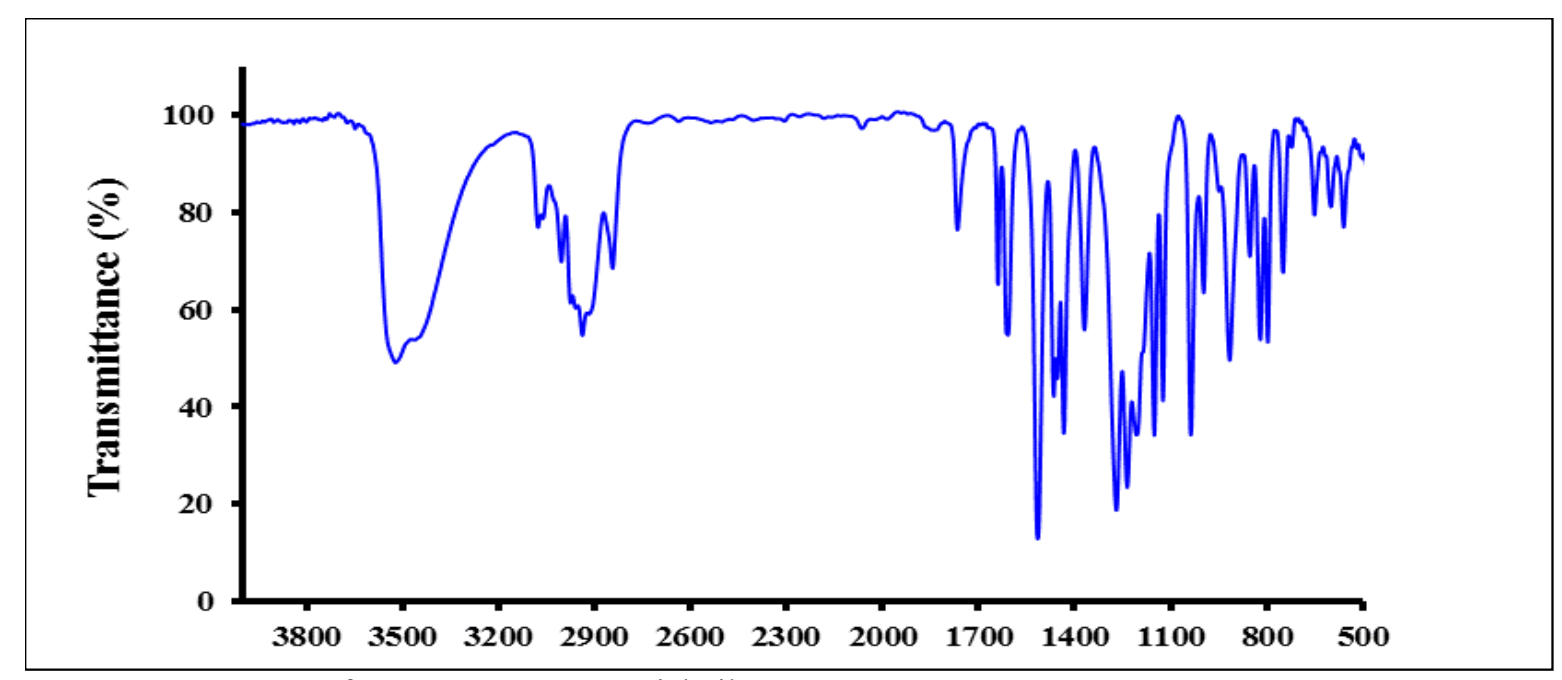

Figure 1 FTIR spectrum of $S$. aromaticum essential oil. 
As can be seen from Table 1, the DPPH-RS activity was increased as the concentration of SAEO increased from 50 to $600 \mu \mathrm{g} \cdot \mathrm{mL}^{-1}$. This means that the SAEO contains bioactive compounds with the ability to neutral DPPH radicals through hydrogen atoms and electron donation (Wang et al., 2016; Jabbari and Jabbari, 2016). The antioxidant capacity measured by ABTS radical test indicated the same trends and relationships as did DPPHRS assay, and the ABTS-RS activity of the essential oil increased as a function of SAEO concentration. This might be due to the same principle of two DPPH and ABTS assays upon reacting with antioxidant compounds (Ćavar et al., 2012). The SAEO was also able to remarkably suppress the rapid discoloration of $\beta$-carotene, and it showed a strong hydroperoxide scavenging power of $66.62 \%$, likely via trapping and neutralizing the linoleate free radicals capable of deterioration of $\beta$-carotene (Barros et al., 2007). This manifestly high antioxidant activity of SAEO is mainly due to its polyphenol compounds, such as phenolic acids and flavonoids.

\section{Antibacterial activity}

The antibacterial effect of SAEO was evaluated by the qualitative and quantitative assays, such as DDA, WDA, MIC, and MBC. As can be seen from Table 2, SAEO showed strong inhibitory effects against $L$. innocua, $S$. aureus, $P$. aeruginosa, and $E$. coli with the inhibition zone values of $27.10,29.15,22.30$, and $20.50 \mathrm{~mm}$ in DDA test and $32.00,35.15,24.40$, and $22.65 \mathrm{~mm}$ in WDA test, respectively. It is clear that the inhibition zone (i.e. higher antibacterial effect) is higher in WDA assay than that in DDA one, mainly due to the direct contact of SAEO and bacteria in the former; however, in the DDA antimicrobial test, the essential oil should be diffused from the discs into culture medium to exert its inhibitory effect (Behbahani, et al., 2017b). It is also worthwhile to note that the gram positive bacteria (L. innocua and $S$. aureus) were inhibited to a more extent by

the essential oil compared to the gram negative bacteria. In addition, the MIC and MBC results revealed that the SAEO was more active against the gram positive bacteria and lower concentration of SAEO was required to inhibit the growth of L. innocua and S. aureus or kill them. This could be probably ascribed to the presence of a single diffusible mucopeptidic laver in gram positive bacteria that makes them more susceptible to antimicrobial agents; whilst, the complex lipopolysaccharide layer on the outer cell membrane of gram negative bacteria have the potential to remarkably reduce the diffusion rate of lipophilic antibacterial compounds across the cell membrane (Behbahani and Imani Fooladi, 2018).

\section{Antibacterial mechanism}

The morphological changes in bacterial cells treated with SAEO were investigated by SEM micrographs. It is clear that the untreated bacteria E. coli and L. innocua had their typical striated wall structures (Figure 2A, B); however, the morphology of cell membranes of the bacteria underwent severe detrimental changes upon treating with SAEO for $12 \mathrm{~h}$ at the MIC values of $1.56 \mathrm{mg} \cdot \mathrm{mL}^{-1}$ for L. innocua (Figure 2A) and $6.25 \mathrm{mg} \cdot \mathrm{mL}^{-1}$ for $E$. coli (Figure 2B). The SEM micrographs revealed that the SAEO treatment was able to manifestly increase the cell permeabilization and membrane integrity disruption. Treated E. coli had a malformed and incomplete/sunken shape in concomitant with the lack of cell walls (Figure 2B). This means that the entirety of the cell membranes was remarkably affected by the essential oil, which could lead to cytoplasm secretion and subsequent cell death. Similar findings were reported by Behbahani, Noshad, and Falah (2019), who worked on the antibacterial mechanisms of cumin essential oil against some pathogenic and spoilage bacteria.

\section{Cytotoxic effect of SAEO}

MTT assay is used to evaluate the cytotoxic effects of essential oils owing to its simplicity. Despite the fact that the assay could not always be the best choice, the activation level of cells could be quantified usefully by this method, through an independent mode with bacteria and eukaryotes' proliferation (Ramak and Talei, 2018).

Figure 3 indicates the cytotoxic effects of different concentrations of SAEO on HT29 cell lines after $24 \mathrm{~h}$ reaction period. The cytotoxicity effect was dependent on the essential oil concentration; the higher SAEO concentration, the higher was cytotoxicity.

Table 1 In vitro antioxidant activity of $S$. aromaticum essential oil.

\begin{tabular}{ccc}
\hline SAEO concentration $(\mu \mathrm{g} / \mathrm{mL})$ & DPPH-RS activity $(\%)$ & ABTS-RS activity $(\%)$ \\
\hline 50 & $29.641 .10^{\mathrm{e}}$ & $27.180 .56^{\mathrm{e}}$ \\
100 & $39.440 .78^{\mathrm{d}}$ & $38.440 .50^{\mathrm{d}}$ \\
200 & $47.620 .92^{\mathrm{c}}$ & $49.810 .10^{\mathrm{c}}$ \\
400 & $57.200 .95^{\mathrm{b}}$ & $61.140 .19^{\mathrm{b}}$ \\
600 & $77.101 .05^{\mathrm{a}}$ & $79.500 .17^{\mathrm{a}}$ \\
\hline
\end{tabular}

Note: Means with different letters in each column differ significantly $(p<0.05)$.

Table 2 In vitro antibacterial activity of $S$. aromaticum essential oil against some pathogenic and spoilage bacteria.

\begin{tabular}{ccccc}
\hline Microbial strains & \multicolumn{4}{c}{ Antimicrobial assays } \\
\cline { 2 - 5 } & $\begin{array}{c}\text { Disk diffusion agar } \\
(\mathbf{m m})\end{array}$ & $\begin{array}{c}\text { Well diffusion agar } \\
(\mathbf{m m})\end{array}$ & MIC $(\mathbf{m g} / \mathbf{m L})$ & MBC $(\mathbf{m g} / \mathbf{m L})$ \\
\hline E. coli & $20.50 \pm 0.55$ & $22.65 \pm 0.28$ & 6.25 & 50 \\
P. aeruginosa & $22.30 \pm 0.56$ & $24.40 \pm 0.44$ & 3.125 & 25 \\
L. innocua & $27.10 \pm 0.40$ & $32.00 \pm 0.23$ & 1.56 & 6.25 \\
S. aureus & $29.15 \pm 0.50$ & $35.15 \pm 0.19$ & 0.78 & 6.25 \\
\hline
\end{tabular}



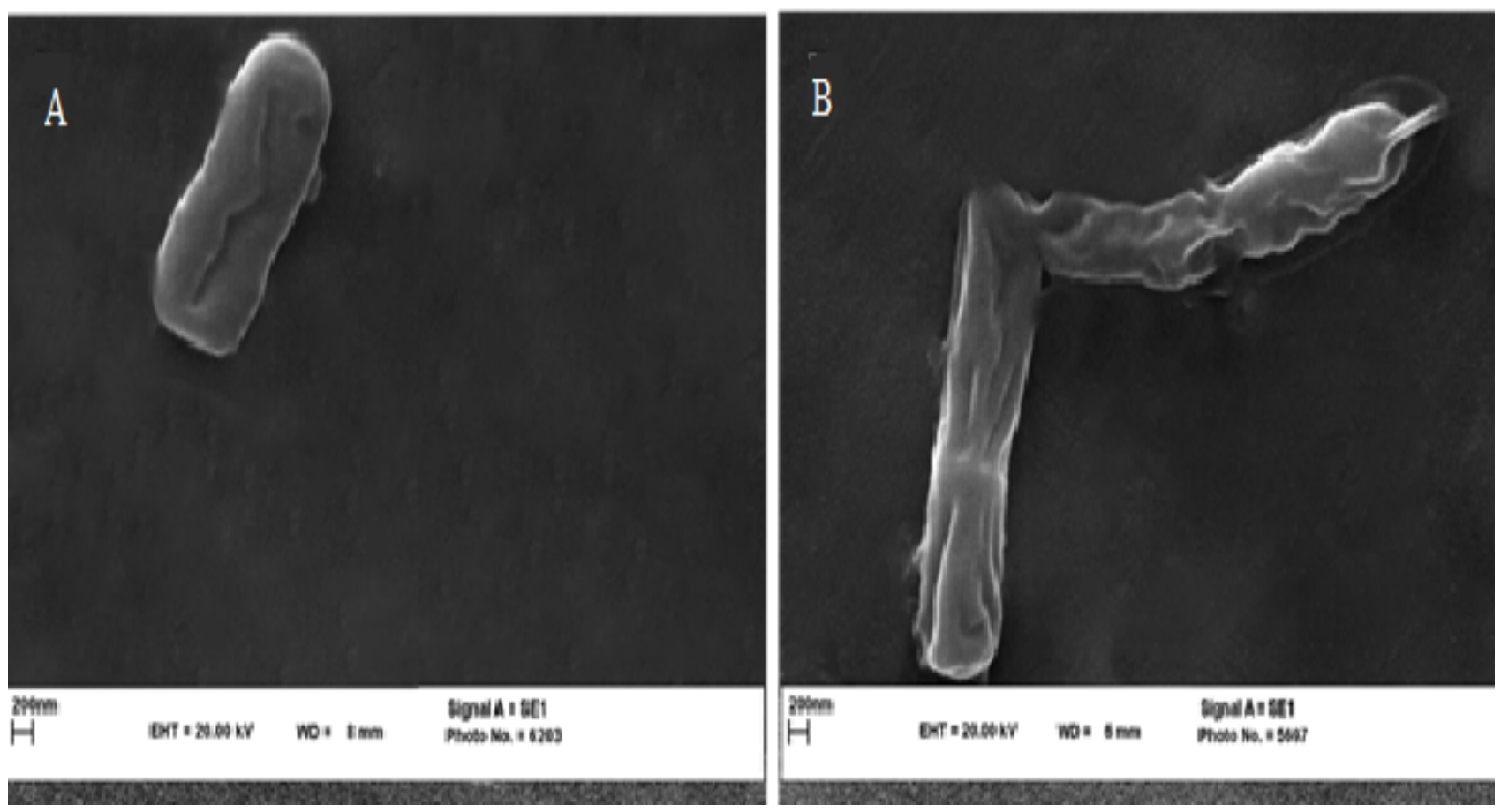

Figure 2 SEM images of L. innocua (A) and E. coli (B) cells after treatment with S. aromaticum essential oil for $12 \mathrm{~h}$.

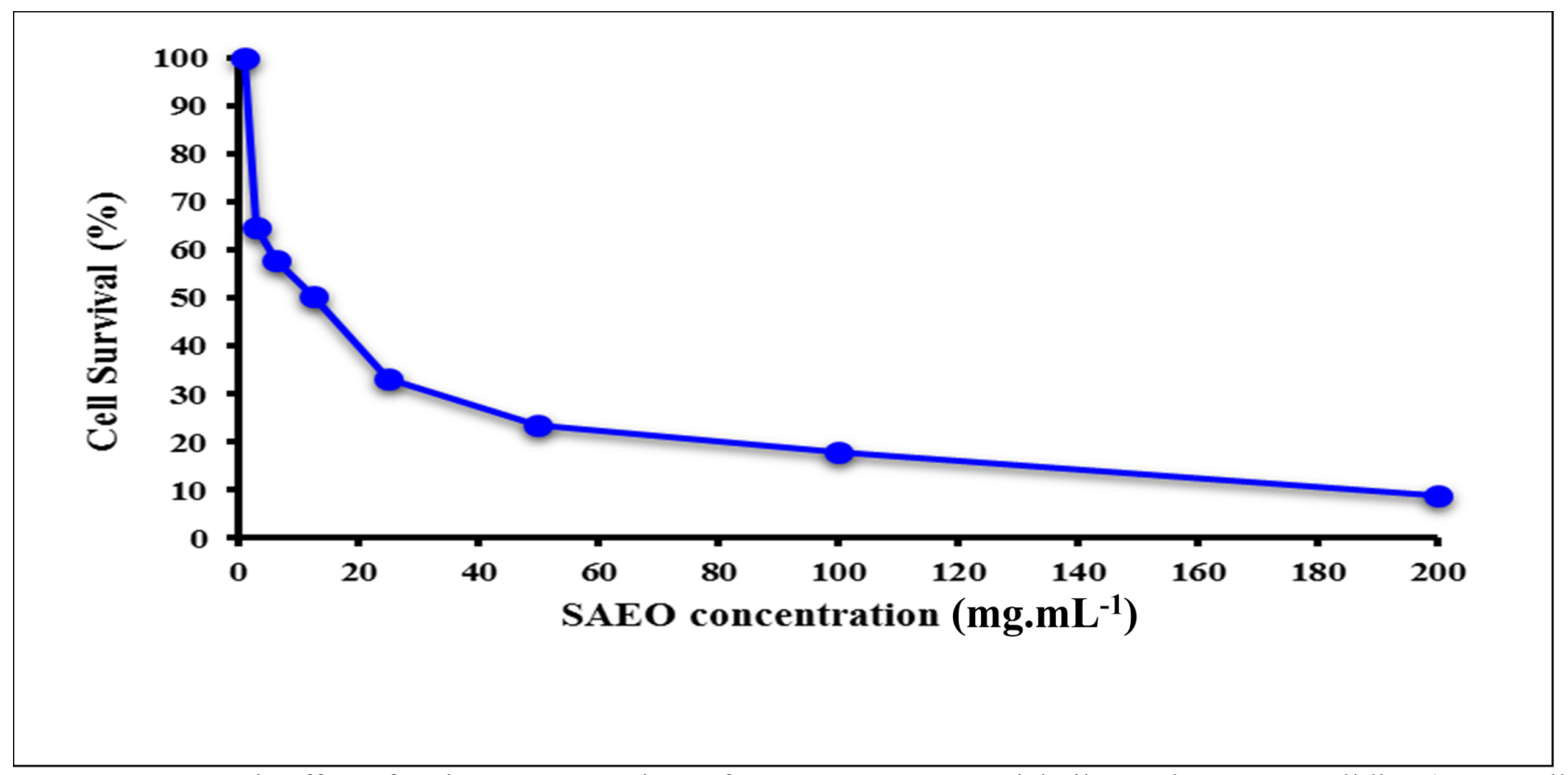

Figure 3 Cytotoxic effect of various concentrations of $S$. aromaticum essential oil on colon cancer cell line (HT29 cell line) after $24 \mathrm{~h}$ reaction period.

It can be seen from Figure 3 that the highest percentage of cell viability was observed at $3.25 \mathrm{mg} / \mathrm{mL}$ SAEO concentration, and a relatively low cell survivability was found when essential oil concentration was increased up to $200 \mathrm{mg} \cdot \mathrm{mL}^{-1}$. It is noteworthy that the $\mathrm{IC}_{50}$ value of the purified active compound was also calculated to check its maximum permissible concentration, and $\mathrm{IC}_{50}$ value was observed to be $13.51 \mathrm{mg} \cdot \mathrm{mL}^{-1}$. It can be confirmed by the MTT data that low concentrations of SAEO could stimulate cell proliferation substantially $(p<0.05)$.

Indeed, essential oils have a lipophilic nature and high affinity for cell membranes. In this way, they could result in manifest changes in the polarization of cancer cell and particularly mitochondrial membranes along with ionic channels and disturbing membrane potential, thereby inhibiting proton pumps and ATP production (Lesgards et al., 2014; Frolova, et al., 2019). It was also reported that essential oils could disrupt the membrane ionic pumps and lead to ion (calcium) and membrane proteins leakage (Bakkali et al., 2008). The cytotoxicity of SAEO and its major components to human skin cell and other herbal extracts through MTT assay have been reported in the literature (Prashar, Locke, and Evans, 2006; Turan et al., 2018; Ogbole, Segun, and Adeniji, 2017). 


\section{CONCLUSION}

A sequential procedure consisted of hydrodistillationbased extraction of $S$. aromaticum essential oil followed by GC-MS analysis of the resultant oily solution yielded a bioactive essential oil rich in eugenol. The essential oil of S. aromaticum had outstanding antibacterial effect against food-borne spoilage and pathogenic bacteria, in conjugation with superb radical scavenging activity. The antibacterial mechanism of $S$. aromaticum essential oil on the most sensitive (i.e. L. innocua) and resistant (i.e. E. coli) bacteria was then evaluated by the SEM micrographs, and it was observed that the essential oil caused an increase in cell permeabilization and membrane integrity disruption. In addition, the essential oil showed a dose-dependent cytotoxic effect on the colon cancer cell line (HT29 cell line) and higher essential oil concentration resulted in a higher cytotoxicity effect. S. aromaticum essential oil could be therefore used to develop functional food products to possibly suppress radical attacks in human body and treat colonic cancers.

\section{REFERENCES}

Alghooneh, A., Behbahani, B. A., Noorbakhsh, H., Yazdi, F. T. 2015. Application of intelligent modeling to predict the population dynamics of Pseudomonas aeruginosa in Frankfurter sausage containing Satureja bachtiarica extracts. Microbial pathogenesis, vol. 85, p. 58-65. https://doi.org/10.1016/j.micpath.2015.06.003

Alizadeh Behbahani, B., Shahidi, F. 2019. Melissa officinalis essential oil: Chemical compositions, antioxidant potential, total phenolic content and antimicrobial activity. Nutrition and Food Sciences Research, vol. 6, no. 1, p. 17-25. https://doi.org/10.29252/nfsr.6.1.17

Bakkali, F., Averbeck, S., Averbeck, D., Idaomar, M. 2008. Biological effects of essential oils-a review. Food and chemical toxicology, vol. 46, no. 2, p. 446-475. https://doi.org/10.1016/j.fct.2007.09.106

Barros, L., Ferreira, M. J., Queiros, B., Ferreira, I. C., Baptista, P. 2007. Total phenols, ascorbic acid, $\beta$-carotene and lycopene in Portuguese wild edible mushrooms and their antioxidant activities. Food chemistry, vol. 103, no. 2, p. 413419. https://doi.org/10.1016/j.foodchem.2006.07.038

Behbahani, A. B., Imani Fooladi, A. A. 2018. Development of a novel edible coating made by Balangu seed mucilage and Feverfew essential oil and investigation of its effect on the shelf life of beef slices during refrigerated storage through intelligent modeling. Journal of food safety, vol. 38, no. 3, p. 1-16. https://doi.org/10.1111/jfs.12443

Behbahani, B. A., Fooladi, A. A. I. 2018. Evaluation of phytochemical analysis and antimicrobial activities Allium essential oil against the growth of some microbial pathogens. Microbial pathogenesis, vol. 114, p. 299-303. https://doi.org/10.1016/j.micpath.2017.11.055

Behbahani, B. A., Noshad, M., Falah, F. 2019. Cumin essential oil: Phytochemical analysis, antimicrobial activity and investigation of its mechanism of action through scanning electron microscopy. Microbial pathogenesis, vol. 136, p. 103716. https://doi.org/10.1016/j.micpath.2019.103716

Behbahani, B. A., Shahidi, F., Yazdi, F. T., Mortazavi, S. A., Mohebbi, M. 2017a. Antioxidant activity and antimicrobial effect of tarragon (Artemisia dracunculus) extract and chemical composition of its essential oil. Journal of Food Measurement and Characterization, vol. 11, no. 2, p. 847-863. https://doi.org/10.1007/s11694-016-9456-3
Behbahani, B. A., Yazdi, F. T., Shahidi, F., Mortazavi, S. A., Mohebbi, M. 2017b. Principle component analysis (PCA) for investigation of relationship between population dynamics of microbial pathogenesis, chemical and sensory characteristics in beef slices containing Tarragon essential oil. Microbial pathogenesis, vol. 105, p. 37-50. https://doi.org/10.1016/j.micpath.2017.02.013

Braga, P. C., Dal Sasso, M., Culici, M., Alfieri, M. 2007. Eugenol and thymol, alone or in combination, induce morphological alterations in the envelope of Candida albicans. Fitoterapia, vol. 78 , no. 6, p. 396-400. https://doi.org/10.1016/j.fitote.2007.02.022

Ćavar, S., Maksimović, M., Vidic, D., Parić, A. 2012. Chemical composition and antioxidant and antimicrobial activity of essential oil of Artemisia annua L. from Bosnia. Industrial Crops and Products, vol. 37, no. 1, p. 479485. https://doi.org/10.1016/j.indcrop.2011.07.024

Cortés-Rojas, D. F., de Souza, C. R. F., Oliveira, W. P. 2014. Clove (Syzygium aromaticum): a precious spice. Asian Pacific journal of tropical biomedicine, vol. 4, no. 2, p. 90-96. https://doi.org/10.1016/S2221-1691(14)60215-X

Dapkevicius, A., Venskutonis, R., van Beek, T. A., Linssen, J. P. 1998. Antioxidant activity of extracts obtained by different isolation procedures from some aromatic herbs grown in Lithuania. Journal of the Science of Food and Agriculture, vol. 77, no. 1, p. 140-146. https://doi.org/10.1002/(SICI)10970010(199805)77:1<140::AID-JSFA $18>3.0$. CO;2-K

Do, Q. D., Angkawijaya, A. E., Tran-Nguyen, P. L., Huynh, L. H., Soetaredjo, F. E., Ismadji, S., Ju, Y. H. 2014. Effect of extraction solvent on total phenol content, total flavonoid content, and antioxidant activity of Limnophila aromatica. Journal of food and drug analysis, vol. 22, no. 3, p. 296-302. https://doi.org/10.1016/j.jfda.2013.11.001

Frolova, N., Uktainets, A., Korablova, O., Voitsekhivskyi, V. 2019. Plants of nepeta cataria var. Citriodora beck. And essential oils from them for food industry. Potravinarstvo Slovak Journal of Food Sciences, vol. 13, no. 1, p. 449-455. https://doi.org/10.5219/1109

Goupy, P., Dufour, C., Loonis, M., Dangles, O. 2003. Quantitative kinetic analysis of hydrogen transfer reactions from dietary polyphenols to the DPPH radical. Journal of Agricultural and Food Chemistry, vol. 51, no. 3, p. 615-622. https://doi.org/10.1021/jf0259381

Jabbari, M., Jabbari, A. 2016. Antioxidant potential and DPPH radical scavenging kinetics of water-insoluble flavonoid naringenin in aqueous solution of micelles. Colloids and Surfaces A: Physicochemical and Engineering Aspects, vol. 489, p. 392-399. https://doi.org/10.1016/j.colsurfa.2015.11.022

Jeyaratnam, N., Nour, A. H., Kanthasamy, R., Nour, A. H., Yuvaraj, A. R., Akindoyo, J. O. 2016. Essential oil from Cinnamomum cassia bark through hydrodistillation and advanced microwave assisted hydrodistillation. Industrial Crops and Products, vol. 92, p. 57-66. https://doi.org/10.1016/j.indcrop.2016.07.049

Lesgards, J. F., Baldovini, N., Vidal, N., Pietri, S. 2014. Anticancer activities of essential oils constituents and synergy with conventional therapies: a review. Phytotherapy Research, vol. 28, no. 10, p. 1423-1446. https://doi.org/10.1002/ptr.5165

Li, Y. Q., Kong, D. X., Wu, H. 2013. Analysis and evaluation of essential oil components of cinnamon barks using GC-MS and FTIR spectroscopy. Industrial Crops and Products, vol. 41, p. 269-278. https://doi.org/10.1016/j.indcrop.2012.04.056 
López-Malo, A., Palou, E., León-Cruz, R., Alzamora, S. M. 2006. Mixtures of natural and synthetic antifungal agents. Advances in food mycology, vol. 571, p. 261-286. https://doi.org/10.1007/0-387-28391-9_18

Lv, F., Liang, H., Yuan, Q., Lìi, C. 2011. In vitro antimicrobial effects and mechanism of action of selected plant essential oil combinations against four food-related microorganisms. Food Research International, vol. 44, no. 9, p. 3057-3064. https://doi.org/10.1016/j.foodres.2011.07.030

Moghayedi, M., Ahmadzadeh, H., Ghazvini, K., Goharshadi, E. K. 2017. Neglected antibacterial activity of ethylene glycol as a common solvent. Microbial pathogenesis, vol. $107, \quad$ p. 457-461. https://doi.org/10.1016/j.micpath.2017.04.022

Mohammed, K. A. K., Abdulkadhim, H. M., Noori, S. I. 2016. Chemical composition and anti-bacterial effects of clove (Syzygium aromaticum) flowers. Int. J. Curr. Microbiol. App. Sci., vol. 5, no. 2, p. 483-489. https://doi.org/10.20546/ijcmas.2016.502.054

Neaz, S. 2019. Phytochemical and biological investigation on syzygium aromaticum (Myrtaceae): dissertation theses. Bangladesh : University of Dhaka.

Noshad, M., Hojjati, M., Behbahani, B. A. 2018. Black Zira essential oil: Chemical compositions and antimicrobial activity against the growth of some pathogenic strain causing infection. Microbial pathogenesis, vol.116, p. 153-157. https://doi.org/10.1016/j.micpath.2018.01.026

Ogbole, O. O., Segun, P. A., Adeniji, A. J. 2017. In vitro cytotoxic activity of medicinal plants from Nigeria ethnomedicine on Rhabdomyosarcoma cancer cell line and HPLC analysis of active extracts. BMC complementary and alternative medicine, vol. 17, no. 1, p. 494. https://doi.org/10.1186/s12906-017-2005-8

Pramod, K., Suneesh, C. V., Shanavas, S., Ansari, S. H., Ali, J. 2015. Unveiling the compatibility of eugenol with formulation excipients by systematic drug-excipient compatibility studies. Journal of Analytical Science and Technology, vol. 6, no. $1, \quad$ p. 34. https://doi.org/10.1186/s40543-015-0073-2

Prashar, A., Locke, I. C., Evans, C. S. 2006. Cytotoxicity of clove (Syzygium aromaticum) oil and its major components to human skin cells. Cell Proliferation, vol. 39, no. 4, p. 241248. https://doi.org/10.1111/j.1365-2184.2006.00384.x

Ramak, P., Talei, G. R. 2018. Chemical composition, cytotoxic effect and antimicrobial activity of Stachys koelzii Rech. f. essential oil against periodontal pathogen Prevotella intermedia. Microbial pathogenesis, vol. 124, p. 272-278. https://doi.org/10.1016/j.micpath.2018.08.010

Ranasinghe, L., Jayawardena, B., Abeywickrama, K. 2002. Fungicidal activity of essential oils of Cinnamomum zeylanicum (L.) and Syzygium aromaticum (L.) Merr et LM Perry against crown rot and anthracnose pathogens isolated from banana. Letters in Applied Microbiology, vol. 35, no. 3, p. 208-211. https://doi.org/10.1046/j.1472765X.2002.01165.X

Ribeiro-Santos, R., Andrade, M., de Melo, N. R., SanchesSilva, A. 2017. Use of essential oils in active food packaging: Recent advances and future trends. Trends in food science \& technology, vol. 61 , p.

132-140.

\section{https://doi.org/10.1016/j.tifs.2016.11.021}

Shan, B., Cai, Y. Z., Sun, M., Corke, H. 2005. Antioxidant capacity of 26 spice extracts and characterization of their phenolic constituents. Journal of agricultural and food chemistry, vol. 53, no. 20, p. 7749-7759. https://doi.org/10.1021/jf051513y
Shokeen, P., Bala, M., Singh, M., Tandon, V. 2008. In vitro activity of eugenol, an active component from Ocimum sanctum, against multiresistant and susceptible strains of Neisseria gonorrhoeae. International journal of antimicrobial $\begin{array}{lllll}\text { agents, vol. } 32, \quad \text { no. } & 2, & \text { p. } & 174-179 .\end{array}$ https://doi.org/10.1016/j.ijantimicag.2008.03.018

Spickett, C. M., Forman, H. J. 2015. Lipid oxidation in health and disease. Boca Raton, USA : CRC Press., 404 p. ISBN 9781482202854. https://doi.org/10.1201/b18138

Srivastava, A. K., Srivastava, S. K., Syamsundar, K. V. 2005. Bud and leaf essential oil composition of Syzygium aromaticum from India and Madagascar. Flavour and Fragrance Journal, vol. 20, no. 1, p. 51-53. https://doi.org/10.1201/b18138

Tohidi, B., Rahimmalek, M., Arzani, A. 2017. Essential oil composition, total phenolic, flavonoid contents, and antioxidant activity of Thymus species collected from different regions of Iran. Food Chemistry, vol. 220, p. 153161. https://doi.org/10.1016/j.foodchem.2016.09.203

Turan, I., Demir, S., Kilinc, K., Yaman, S. O., Misir, S., Kara, H., Deger, O. 2018. Cytotoxic effect of Rosa canina extract on human colon cancer cells through repression of telomerase expression. Journal of Pharmaceutical Analysis, vol. 8, no. 6, p. 394-399. https://doi.org/10.1016/j.jpha.2017.12.005

Wang, G., Huang, X., Pei, D., Duan, W., Quan, K., Li, X., Di, D. 2016. DPPH-HPLC-DAD analysis combined HSCCC for screening and identification of radical scavengers in Cynomorium songaricum Rupr. New Journal of Chemistry, vol. 40. no. 4, p. 3885-3891. https://doi.org/10.1039/C5NJ03233D

Wojdyło, A., Oszmiański, J., Czemerys, R. 2007. Antioxidant activity and phenolic compounds in 32 selected herbs. Food chemistry, vol. 105, no. 3, p. 940-949. https://doi.org/10.1016/j.foodchem.2007.04.038

Yeganegi, M., Yazdi, F. T., Mortazavi, S. A., Asili, J., Behbahani, B. A., Beigbabaei, A. 2018. Equisetum telmateia extracts: Chemical compositions, antioxidant activity and antimicrobial effect on the growth of some pathogenic strain causing poisoning and infection. Microbial pathogenesis, vol.. $\quad 116, \quad$ p. $\quad 62-67$. https://doi.org/10.1016/j.micpath.2018.01.014

Zhang, L., Zhang, T., Chang, M., Lu, M., Liu, R., Jin, Q., Wang, X. 2019. Effects of interaction between $\alpha$-tocopherol, oryzanol, and phytosterol on the antiradical activity against DPPH radical. $L W T$, vol. $112, \quad$ p. 108206. https://doi.org/10.1016/j.lwt.2019.05.104

Zhang, Y., Liu, X., Wang, Y., Jiang, P., Quek, S. 2016. Antibacterial activity and mechanism of cinnamon essential oil against Escherichia coli and Staphylococcus aureus. Food Control, vol. 59, p. 282-289. https://doi.org/10.1016/j.foodcont.2015.05.032

Zhong, N. J., Liu, G. Q., Zhao, X. H., Gao, Y. Q., Li, L., Li, B. 2015. Lipid Peroxidation Inhibitation Activity of Maillard Reaction Products Derived from Sugar-amino Acid Model Systems. Advance Journal of Food Science and Technology, vol. 9, no. 5, p. 393-397. https://doi.org/10.19026/ajfst.9.1922

\section{Acknowledgments:}

The authors wish to express their gratitude to Research Deputy of Agricultural Sciences and Natural Resources University of Khuzestan and National Elites Foundation for funding this study. 


\section{Contact address}

*Behrooz Alizadeh Behbahani, Agricultural Sciences and Natural Resources University of Khuzestan, Faculty of Animal Science and Food Technology, Department of Food Science and Technology, Postal Code: 6341773637, Mollasani, Iran, Tel.: +989168729619,

E-mail: B.alizadeh@asnrukh.ac.ir

ORCID: https://orcid.org/0000-0002-1447-5088

Mohammad Noshad, Agricultural Sciences and Natural Resources University of Khuzestan, Faculty of Animal Science and Food Technology, Department of Food Science and Technology, Postal Code: 6341773637, Mollasani, Iran, Tel.: +989173238580,
E-mail:Noshad@asnrukh.ac.ir

ORCID: https://orcid.org/0000-0002-4060-9254

Fereshteh Falah, Ferdowsi University of Mashhad, Faculty of Agriculture, Department of Food Science and Technology, Azadi Street, Postal Code: 9177948974, Mashhad, Iran, Tel: +989174059029,

E-mail: Fereshtefalah11@gmail.com

ORCID: https://orcid.org/0000-0001-8991-8755 